This document is the accepted manuscript version of the following article:

Joncourt, S., Gebauer, H., Reynoso, J., Cabrera, K., Valdes, A., \& Greve, K. (2019). Extending the base-of-the-pyramid concept. Service Science, 11(3), 155-261. https://doi .org/10.1287/serv.2019.0247

\title{
EXTENDING THE BASE-OF-THE-PYRAMID (BOP) CONCEPT
}

\section{ABSTRACT}

The Base-of-the-Pyramid (BoP) concept plays a prominent role among the market-based perspectives for poverty alleviation. Previous literature reviews discuss the evolution of the BoP concept as a research domain, however several major research streams that approach the phenomenon from distinct angles have been overlooked. To address these shortcomings, we continue these reviews and formulate recommendations for theoretical and empirical advancement by considering emerging research domains. We use the problematization method to identify in-house and field assumptions shared across research domains and test them through critical empirical and theoretical interrogation. Therefore, we extend the original BoP concept by considering emerging research domains that have been neglected in earlier studies, including Corporate Social Responsibility, Inclusive Business, Microfinance, Non-Profit Expansion, Social Entrepreneurship, and Subsistence Marketplaces. We also revise the BoP business model idea and develop a framework that highlights key dimensions for management research in BoP markets. These dimensions include business ecosystems, financial viability, innovativeness, resource scarcity, role of the poor and scalability. For each dimension, we develop future research questions.

Keywords: Base-of-the-Pyramid, poverty alleviation, literature review, inclusive business, business ecosystems, innovativeness, scalability.

\section{Simon Joncourt,a Heiko Gebauer,a Javier Reynoso,b Karla Cabrera,b Ana Valdes,b Katharina Greve c}

a Swiss Federal Institute of Aquatic Science and Technology (Eawag), CH-8600 Dübendorf, Switzerland; b EGADE Business School, Tecnologico de Monterrey, Monterrey, 66269 San Pedro Garza Garc'ia, Nuevo Le'on, Mexico;

c Institute for Manufacturing, University of Cambridge, Cambridge CB3 0FS, United Kingdom

Contact: simon.joncourt@eawag.ch (SR); heiko.gebauer@eawag.ch (HG); jreynoso@tec.mx, 


\section{INTRODUCTION}

The market-based perspective is becoming increasingly popular by promoting the idea that poverty is a situation of unmet needs and thus simultaneously a business opportunity for the private sector (Prahalad 2004, London and Hart 2010). The Base-of-the-Pyramid (BoP) concept contributes prominently to the market-based perspective. This concept considers the needs of the four billion people living on less than 2,000 dollars a year as a business opportunity for companies (Prahalad and Hammond 2002; Prahalad 2004, 2012). Companies can tap into BoP markets in order to generate additional revenues, introduce new technologies and reduce the poverty penalty which is a term that refers to the relatively higher cost shouldered by the poor, when compared to the non-poor in order to access products and services (Prahalad 2004; Gebauer, Haldimann and Saul 2017). An estimated \$5 trillion in purchasing power parity (World Resources Institute 2007; Sanchez and Schmid 2013; Financial Times Lexicon 2017) attracts companies to enter this largely untapped market in order to convert customer needs into aspirational products and services relatively cost-efficiently (Prahalad, 2012; Polak 2013).

Since 2000, the BoP concept has gained momentum. Academics have defined the BoP market and provided empirical evidence on how firms can succeed in it. In service research, for example, the BoP concept has been finally embraced, after the long-term call to increase the understanding of services in low-income settings (Reynoso 1999). This novel approach is helping to expand the scope of traditional service theories which might not be applicable in the BoP context, or at least not always nor in the same way (Gebauer and Reynoso 2013). In this vein, well established BoP research has been explored recently in the light of service research priorities (Ostrom et al. 2015), leading to a proposal for breaking new ground in the domain of BoP service research (Reynoso et al. 2015). Consequently, in recent years, there has been an increasing interest in studying services at the BoP. This is evidenced by calls for further research (e.g., Fisk, et al. 2016), recent articles published in top service management journals such as JoSM and JSR (e.g., Martin and Hill 2015; Schaefers et al. 2018) and book chapters (e.g., 
Cipolla and Reynoso 2017; Rubalcaba et al. 2018), as well as by several call for papers, presentations and special sessions on this topic at top service conferences such as Frontiers in Services, SERVSIG, IRSSM and QUIS. These efforts are in turn fostering new initiatives to discuss and disseminate emerging knowledge in this field. This paper, for example, is the result of one of the research groups' work that emerged from the 2017 Service Week Conference organized and held at University of Cambridge.

Despite considerable research intensity, the BoP concept has not reached maturity yet (Reficco and Gutierrez 2016; Dembek et al. 2019). There is still a need for its theoretical and empirical advancement. Thus, this article aims to contribute to the further advancement of the BoP concept by analyzing articles published between 2009 and 2014, building on a review of the BoP concept that included articles published between 1999 and 2009 (Kolk et al. 2014). We add previously neglected research domains of Corporate Social Responsibility, Inclusive Business, Microfinance, Non-profit Expansion, Social Entrepreneurship, and Subsistence Marketplaces into the BoP concept. Additionally, we applied the problematization methodology proposed by Alvesson and Sandberg (2011) to develop field assumptions for a broader BoP concept. Field assumptions are a broader set of assumptions about a specific topic that are shared by multiple schools of thought within and across paradigms (Alvesson and Sandberg 2011). These field assumptions are used to develop future research questions which contribute to extending the BoP concept.

The next section summarizes the evolution of the BoP concept describing its in-house assumptions. These types of assumptions exist within a particular school of thought in the sense that they are shared and accepted as unproblematic by its advocates (Alvesson and Sandberg 2011). The third section describes the methodology for problematizing the in-house assumptions and aggregating them into field assumptions. Section four describes these field assumptions, evaluates their current status and discusses the necessary theoretical and empirical 
advancements for the BoP concept. Section five concludes the article and presents themes for future research.

\section{ORIGINAL BOP CONCEPT}

\section{Evolution of the original BoP concept}

The original BoP concept refers directly or indirectly to Prahalad and Hammond's seminal contribution "Serving the World's poor, Profitably" which was published in Harvard Business Review in 2002. This article was the first to introduce the Bottom/Base of the Pyramid (BoP) approach by calling for the world's wealthiest companies to seek their fortunes while helping bring prosperity to the poor by building businesses aimed at this segment (Prahalad and Hammond, 2002). The evolution of this BoP concept has been expressed as moving from BoP 1.0 to 2.0 and lately to 3.0 (Simanis and Hart 2008; Cañeque and Hart 2015). The idea of selling products and services to the poor dominated BoP 1.0 (Prahalad and Hart 2002; Simanis and Hart 2008). Under this paradigm, multinational enterprises (MNEs) listen to the BoP consumer in order to understand their needs and preferences. This knowledge is converted into product adaptations, better packaging designs, and distribution channels that disrupt the current price points, specifically reducing the poverty penalty, which refers to the phenomenon that poor people pay relatively higher prices for basic products and services (Prahalad 2004; Mendoza 2011). BoP 2.0 is about engaging in a dialogue with poor people to stimulate the generation of new solutions for poverty alleviation. Under this paradigm people are considered as coproducers and co-inventors (Simanis and Hart 2008). In contrast, BoP 3.0 is concerned with developing business strategies even further, by moving towards open innovation approaches and more participatory governance structures making use of the "wisdom of the crowd" to realize previously unimagined solutions (Cañeque and Hart 2015). 
BoP research has become a dynamic research domain with an increasing number of articles. With 100 articles per year, a first peak was reached in 2012, according to Scopus Database. Figure 1 highlights the major milestones in the evolution of the original BoP concept.

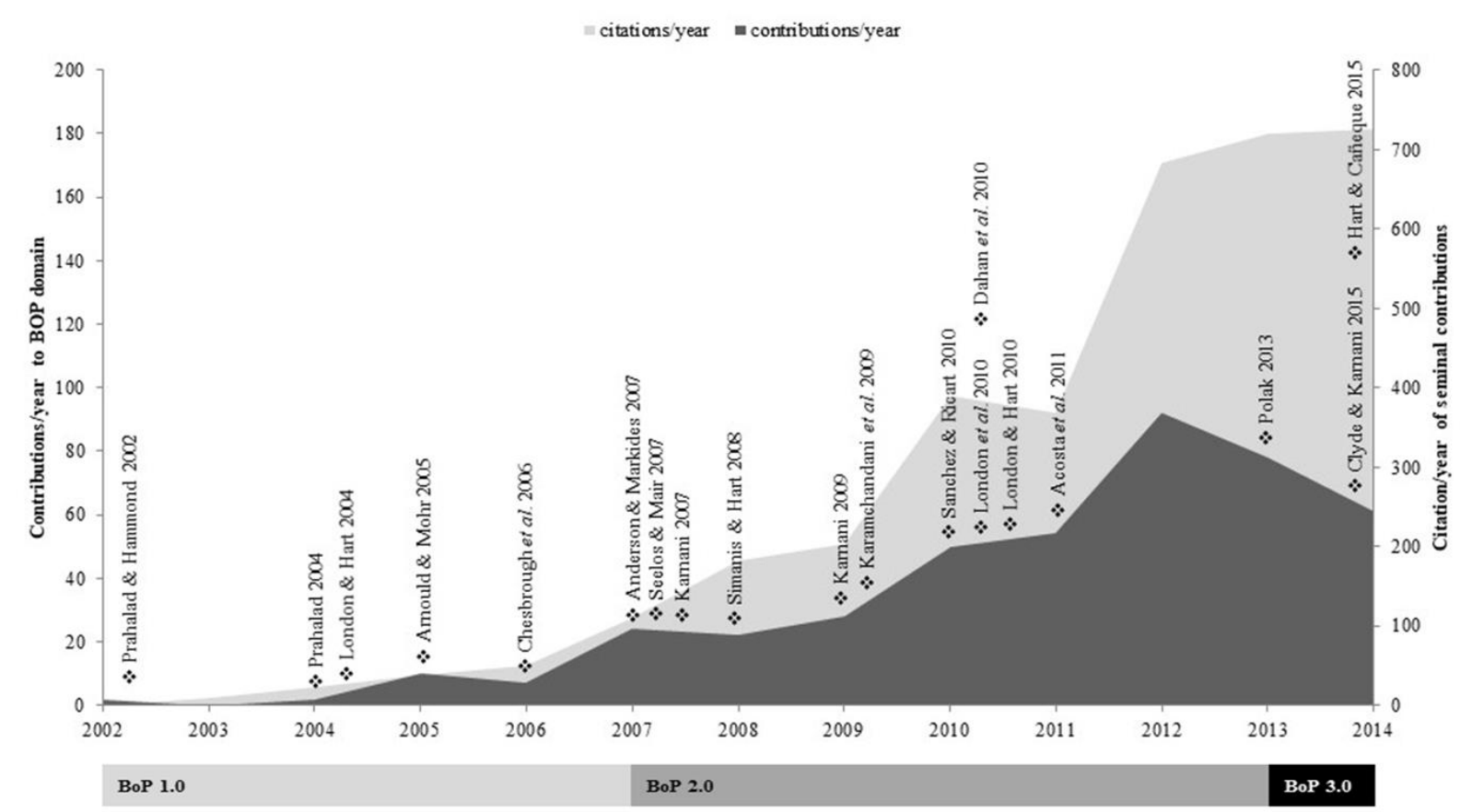

Figure 1: Evolution of the BoP Concept

Along the evolution of the BoP research domain, different in-house assumptions have been identified and discussed in the literature, including the revenue model (e.g., Prahalad 2004), financial constraints (e.g., Vachani and Smith 2008, Mendoza 2011, Mair and Marti 2009), role of the poor (e.g., Karnani 2009; London et al. 2010), innovativeness (e.g., Chesbrough et al. 2006; Seelos and Mair 2007), cooperation (e.g., Clyde and Karnani 2015), and economies of scale (e.g., Seelos and Mair 2007). The revenue model suggests that companies cover their costs with revenue generated by selling products and/or services to the poor which can even produce profits. Financial constraints relate to the low-income levels in terms of segmenting the BoP market. The role of the poor assumes a mode of engagement as co-inventors or 
recipients and positions them in the value network as consumers or entrepreneurs. Innovativeness suggests that companies go beyond a simple adaptation of products and services. They should attempt to create new products and services, which are desired by the poor, remain affordable and overcome the poverty penalty. This requires innovation activities in individual business processes as well as at the business model level. Such innovation activities need cooperation with non-profit organizations. Finally, the BoP original concept assumes economies of scale for products and services. Such economies of scale reduce costs, which facilitate the revenue model by making it more likely to achieve cost coverage and even profits. The first column in Table 2 summarizes these in-house assumptions of the original BoP concept (see "In-house and field assumptions" in the results sections of this article).

\section{RESEARCH METHOD}

There are different ways for conducting and examining literature reviews for building an extended BoP concept and to formulate future research questions. Bibliometric methods, such as co-citation analysis, bring a level of objectivity and quantitative analysis to the literature review, which reduces the level of bias inherent in approaches, such as expert surveys or traditional literature reviews (Nerur et al. 2008). Bibliometric methods can be used to analyze the history of a research domain and identify gaps in the literature to which researchers have not paid particular attention thus far. On the other hand, these methods tend to reinforce already influential theories in a way that underproblematize existing literature and the assumptions on which they are based (Alvesson and Sandberg 2011). We therefore rely on a traditional method for literature review, namely content analysis.

When analyzing article contents, researchers can look either into the empirical gaps that individual articles try to close or, into their theoretical assumptions. The latter is considered a problematization methodology, which is especially useful for identifying core assumptions and 
coming up with novel research questions in line with the identified assumptions (Alvesson and Sandberg 2011).

Our problematization methodology followed specific steps, which we present sequentially in figure 2 (see below), but the actual process we adopted was more iterative (Alvesson and Sandberg 2011). A descriptive analysis of the BoP including its geographical scope, its products and services, and its initiatives as well as research methods and theoretical lenses supplement the problematization method.

First, we identified relevant research domains for extending the BoP concept by considering Kolk et al.'s (2014) recommendations. For this article we decided to focus on Microfinance, Subsistence Marketplaces, Inclusive Business, Social Entrepreneurship, Corporate Social Responsibility and Non-Profit Expansion. Among these, Corporate Social Responsibility and Non-Profit Expansion are not identified by those authors. However, we decided to include Corporate Social Responsibility because a BoP-venture can be part of a company's effort to recover costs of its CSR department. We also included Non-Profit Expansion because it looks into how non-profit organizations can scale-up their activities sustainably by adopting a market-based approach. On the other hand, although Kolk and colleagues recommend taking it into account, we decided not to include Development Economics as it has a dominant macro-economic perspective and typically uses analytical units other than that of the organization (e.g. regions, nations, households, income segments, etc.). For similar reasons, additional research domains considering international market entry and strategic management could not be taken into account in the present study.

Second, since each domain is informed by a large number of articles, our next step was to select the most relevant contributions in each domain that are available on the Scopus database. We searched for contributions that correspond to the definition of path defining studies (Kuhn 2003), representing milestones for the conceptual advancement of a research domain. To identify milestones, we relied on both the number of citations of relevant articles 
as well as a qualitative evaluation of their potential for theoretical advancement and their influence on subsequent publications. In this vein, some authors suggest that the number of citations a paper receives provide informative trend data (Moed 2005), and is thus frequently used as a measure of its impact (Ware and Mabe 2015). Even though there is not a consensus, in general, papers reach their citation peak between two and six years after publication (Amin and Mabe 2000). But in social sciences, this peak may take up to 10 years (Archambault and Larivière 2010). Considering this information, search parameters were therefore restricted to articles that had been published by the end of 2014 and that were included in the search categories Economics, Econometrics and Finance, Business, Management and Accounting, and Social Sciences as they are defined by Scopus. For each domain, we used a set of keywords to identify the contributions (see notes in Table A1 in the appendix). Articles that received a major share (more than $30 \%$ ) of total citations of the research domain were considered highly influential and thus potential path-defining studies. Their significance for subsequent publications within the corresponding domain was then qualitatively apprehended one-by-one to refine the selection of literature milestones. For publications from 2012 and later, we accounted for the fact that they tend to have less citations due to their newness by using relative values such as citations/year in comparison to other articles with similar publication dates.

Overall, we selected 94 articles which are presented in Table A1 (see appendix). The articles are classified into seven domains: Original BoP concept (36), Corporate Social Responsibility (15), Inclusive Business (5), Non-Profit Expansion (8), Microfinance (11), Social Entrepreneurship (7) and Subsistence Marketplaces (12).

Third, we articulated the in-house assumptions underlying each of those domains. Inhouse assumptions are a set of ideas held by a theoretical school about a specific subject matter and shared by advocates of this research domain. As mentioned in the previous section, the inhouse assumptions of the original BoP concept identified were: revenue model, financial constraints, innovativeness, role of the poor, cooperation and economies of scale. To identify 
them, we read the selected contributions belonging to one domain. We followed Alvesson and Sandberg's (2011) recommendation to scrutinize internal debates, analyze the narrative style and vocabulary. For example, Karnani (2007, p.104) has scrutinized Prahalad's (2004, p. 1) narrative style on the "... poor as ... resilient and creative entrepreneurs and value-conscious consumer" leading to the debate on whether the original BoP concept romanticizes the poor. Such an examination led us to the list of in-house assumptions. To ensure reliability of the assumptions independent researchers scrutinized the articles and verified the accuracy of the assumptions. The level of inter-judge reliability (Perreault and Leigh 1989) was in accordance with Rust and Cooil's "rule of thumb" (the authors recommend a minimum inter-judge reliability level of .70) for evaluating the reliability of coding qualitative data for exploratory research (Rust and Cooil 1994).

Fourth, we compared this list of in-house assumptions across all domains. The in-house assumptions that were shared among all domains became field assumptions. These field assumptions are a broader set of assumptions about business approaches for poverty alleviation. Our analysis resulted on six-field assumptions (role of the poor, resource constraints, scalability, business ecosystems, financial viability, and innovativeness).

Finally, the comparison of assumptions enables us to problematize the current status of the field assumptions. We discussed whether or not the field assumptions are considered fully in the empirical work and went through the logic of what could be to develop future research questions (Peirce 1994). The discussion with other scholars and practitioners supported us in developing the future research questions (Alvesson and Sandberg 2011, p. 259). 


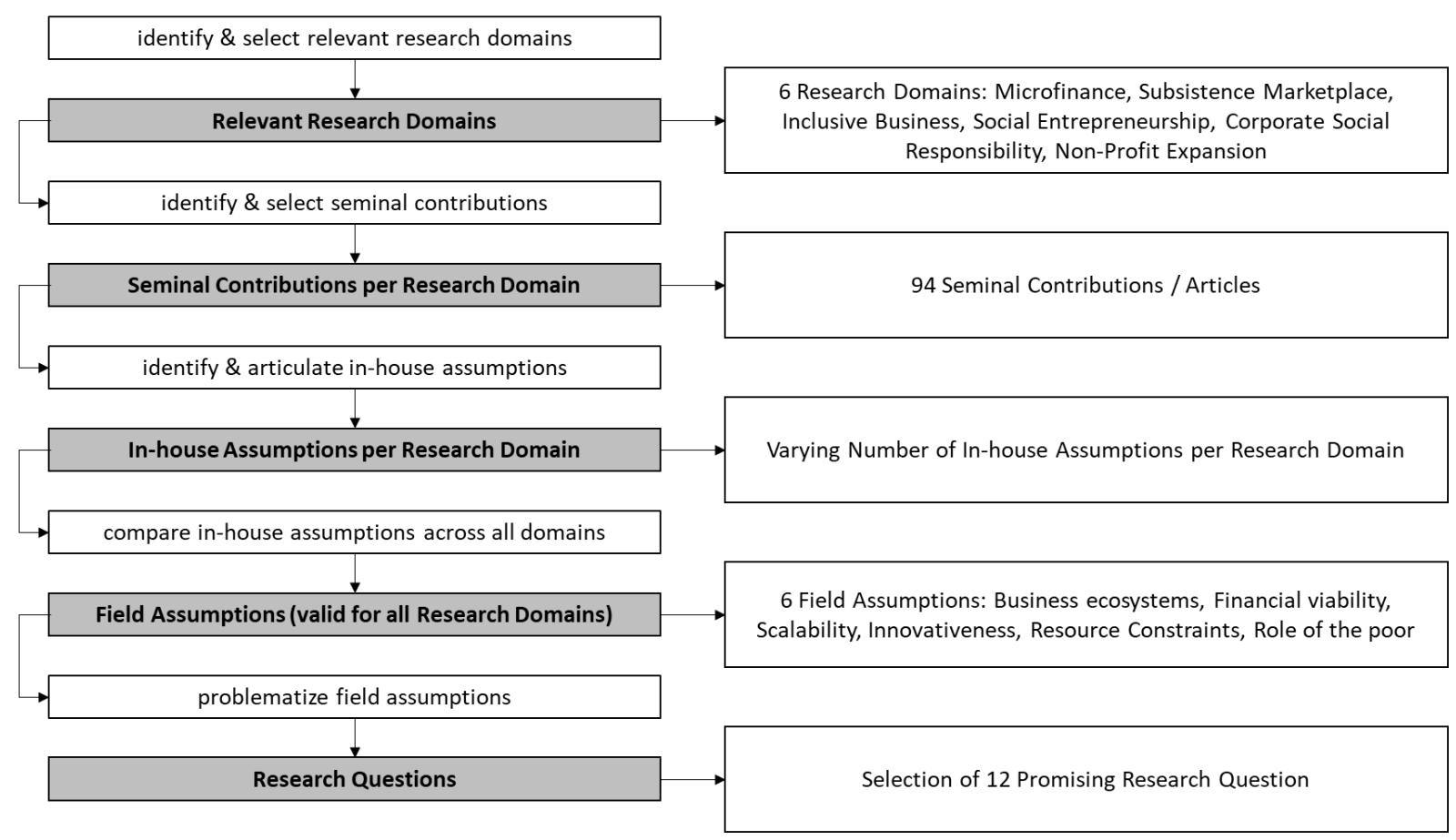

Figure 2: Summary of the research process and corresponding outputs

\section{RESULTS}

We present our results in the following way: first, we present a descriptive analysis, followed by the discussion of the in-house and field assumptions; third, we provide insights into the current status of the empirical work according to the field assumptions; fourth, we develop future research questions.

\section{Descriptive results}

Table 1 summarizes the descriptive results. Most authors that write about BoP markets are affiliated to universities in industrialized countries. Very few researchers from low-income countries themselves have contributed to the evolution of the BoP domain (e.g., Karnani 2007, Viswanathan et al. 2010). Practitioner journals such a Harvard Business Review (6) and California Management Review (5) still have a relatively high share of articles discussing the concept. The relatively important role of such journals suggests that BoP markets are still controversially discussed among practitioners and that practitioner-oriented publications help 
legitimize the BoP concept. Additionally, the BoP topic is driven by multiple journals, including high impact journals, such as Academy of Management (3), Journal of Marketing (1) or Journal of Management Studies (4), and covering various disciplines, such as economics (e.g., Journal of Development Economics (2)), business ethics (e.g., Journal of Business Ethics (2)) international management (e.g., Journal of International Business Studies (1), International Business Review (2)), entrepreneurship (e.g., Journal of Business Venturing (1) and Entrepreneurship: Theory and Practice (4)), marketing (e.g., Journal of Consumer Marketing (4) and Journal of Public Policy and Marketing (3)), and general management (e.g., Journal of Business Research (7)).

\begin{tabular}{|c|c|}
\hline $\begin{array}{l}\text { Organizations } \\
1\end{array}$ & $\begin{array}{l}\text { Grameen Group (27), Hindustan Unilever Limited (22), CEMEX (8), ITC Limited } \\
\text { (8), Bangladesh Rural Advancement Committee (BRAC) (7), BancoSol (6), } \\
\text { Procter \& Gamble (5), Smart Communications Inc. (5), Aravind Eye Hospital (4), } \\
\text { BP (4), Nestl, (4), SC Johnson (4), TATA (4), Voxiva (4), ABB Group (3), Coca- } \\
\text { Cola (3), Dupont (3), Hewlett-Packard (HP) (3), Honey Care Africa (3), Jaipur } \\
\text { (3), Sekem (3), Vodafone (3), Aga Khan Support Program (AKRSP) (2), Amanco } \\
\text { (2), Avon (2), Badan Kredit Desa (2), Bangladesh Rural Development Board } \\
\text { (BRDB) (2), CavinKare (2), Celtel (2), Haier Group (2), Honda (2), ICICI (2), } \\
\text { Kraft Foods (2), Microsoft International (2), Myrada (2), Nike (2), Nokia (2), } \\
\text { Philips (2), Plan Pueblo (2), Shell (2), TARAhaat (2), Tiviski Dairy (2), } \\
\text { VisionSpring (2), Wizzit (2) (remaining (245)*; n/a (17)) }\end{array}$ \\
\hline $\begin{array}{l}\text { Products \& } \\
\text { services }^{2}\end{array}$ & $\begin{array}{l}\text { Banking \& Finance (62), Rural Development (60), ICT Service (58), Consumer } \\
\text { non-durables (55), Consumer durables (42), Arts/crafts (32), Health care services } \\
\text { (19), Resource extraction (10), Energy supply (6), Insurance (6), Social Service } \\
\text { (6), Water supply (6), Business Service (4), Tourism (4), various (3), Educational } \\
\text { Service (2), Energy Service (2), Food (2), food supply (2), Waste Treatment } \\
\text { Service (2), Cars (1), Chemicals supply (1), Forestry (1), Leather(1), pharmacy } \\
\text { (1), Transportation Service (1) (n/a (52) }\end{array}$ \\
\hline Country $^{2}$ & $\begin{array}{l}\text { India (95), Bangladesh (44), Kenya (20), Brazil (12), Philippines (10), China (9), } \\
\text { Bolivia (8), Cameroon (8), Latin America (8), Lebanon (8), Peru (8), South Africa } \\
\text { (8), USA (8), Venezuela (8), Mexico (7), Guatemala (6), Indonesia (6), Nigeria } \\
\text { (6), Sri Lanka (6), Tanzania (6), Uganda (6), Canada (5), Central America (5), } \\
\text { Various (5), Africa (4), Honduras (4), Zimbabwe (4), Colombia (3), Egypt (3), } \\
\text { Ethiopia (3), Haiti (3), Pakistan (3), Senegal (3), Vietnam (3), Angola (2), } \\
\text { Azerbaijan (2), Ecuador (2), El Salvador (2), Ghana (2), Guinea (2), Nepal (2), } \\
\text { Benin (1), Chile (1), Costa Rica (1), Japan (1), Laos (1), Malaysia (1), Mauritania } \\
\text { (1), Nairobi (1), Nicaragua (1), Niger (1), Rwanda (1), Spain (1), Swaziland (1), } \\
\text { Thailand (1), United Kingdom (1), Zambia (1) }\end{array}$ \\
\hline $\begin{array}{l}\text { Literature } \\
\text { streams }^{2}\end{array}$ & $\begin{array}{l}\text { Innovation ((22) - Enterpreneurship (10) and Organization (12)), Marketing }{ }^{+}(19) \text {, } \\
\text { CSR theories (14), Organizational theories (8) Growth (3), Networks (3), } \\
\text { Principal-Agent Theory (2), Social Capital (2), Knowledge management (1), } \\
\text { Institutional logics (1), Institutional theory and transaction costs economics (1), }\end{array}$ \\
\hline
\end{tabular}

\footnotetext{
${ }^{1}$ Note: Multiple answers possible.
} 


\begin{tabular}{l|l}
\hline & $\begin{array}{l}\text { Anthropology (1), theorizing microcredits (1), Competitive dynamics (1), } \\
\text { Corporate citizenship (1), Neoclassical theory (1), Neoliberalism (1), n/a (19) }\end{array}$ \\
Research & $\begin{array}{l}\text { ANCOVA Analysis (1)**, Conceptual paper (28), Interviews (25), Case study } \\
\text { methods }\end{array}$ \\
& $\begin{array}{l}\text { analysis (24), Observations (16), Panel data analysis (2), Surveys (2), } \\
\text { Ethnographic case method (2), Buying Power Index (1), Experiments (1), Focus } \\
\text { Groups (1), Panel Surveys (1), Secondary Data Collection (1), Statistical } \\
\text { Comparative analysis (2)**, Testimonies (1), n/a (17) }\end{array}$ \\
\hline
\end{tabular}

Table 1: Descriptive results. ${ }^{2}$

According to the empirical evidence, the geographical scope is 49 countries. There is a particularly strong focus on India with 95 cases, followed by Bangladesh with 44, Kenya with 20, and Brazil with 12. The body of work on Bangladesh comprises a few case studies, namely Bangladesh Rural Advancement Committee (BRAC) and members of the Grameen Group, including Grameen Bank, Grameen Shakti, Grameen Danone, and Grameen Veolia. There are few cases, which are reported very frequently such as Grameen Group (27), Hindustan Unilever Ltd (21), ITC Limited (9), Cemex (8), BRAC (7), BancoSol (6), or Procter and Gamble (5). The BoP concept is not only relevant in low-income countries, but also in newly industrializing countries (e.g., Brazil (12), China (9), India (95), and South Africa (12)).

We applied NAICS coding system to categorize products and services to the extent it was possible (US Census Bureau 2017). When it comes to the type of products and services for the BoP initiatives, 32 cases refer to handicraft enterprises offering a variety of products and services. Among the remaining products and services, banking and finance (62), rural development services (60), ICT service (58), consumer non-durables (55), and consumer durables (42) are the most often investigated cases. Services and products relating to the Millennium Developments Goals (MDGs) such as water (6) or energy supply services (7) play a minor role. A noteworthy exception is Grameen Shakti, which has become one of the world largest providers of solar home systems.

\footnotetext{
${ }^{2}$ Note: * Organizations that appear once in the literature sample, ** Quantitative research methods,
} 
The theoretical grounding of most of the articles included in the analysis is relatively weak. This could be partially explained by the argument that established theories derived in the industrialized market are not applicable to $\mathrm{BoP}$ markets in the same way (Burgess and Steenkamp 2006, Bruton 2010). The nature of the audience of practitioner journals and the fragmentation of the literature streams in academic publications might also contribute to the limited theoretical grounding. For instance, articles in the CSR domain generally refer to its own CSR theory for conceptual development and implications. However, other research domains incorporate different, and sometimes multiple, literature streams, such as Innovation (22), Marketing (19) or Organizational theories (8), to name a few. For example, social entrepreneurship articles are built strongly on Innovation literature, which is focused on the individual entrepreneur (10), while inclusive business articles also rely on Innovation literature, but with an organizational perspective (12). The Marketing literature stream is frequently found in the analyzed articles, but only a few of these articles go deep into marketing theory. There are three exceptions: Chikweche and Fletcher (2010) argue that purchases in BoP markets are strongly based on consumer behavior; Karnani (2009) focuses on the reality of consumption and entrepreneurship in BoP markets; and London et al.'s (2010) distinguish marketing relationships by focusing on value capture and value creation.

Despite the importance of networks at the $\mathrm{BoP}$ as a way for coping with resource scarcity, only three articles build on this literature stream, exploring alliances (Perez-Aleman and Sandilands 2008, Seelos and Mair 2007) and industry clusters (Arnould and Mohr 2005). Social capital as an important asset in informal and community networks is a literature stream mentioned in two articles (Rankin 2002, Mayoux 2001).

Interestingly, Non-Profit Expansion articles rely strongly on the growth literature stream. They explicitly describe the resources and organizational capabilities (e.g., staffing, communicating, alliance building, lobbying, earning generations, replicating, and stimulating market forces) necessary to scale the social impact (Bloom and Chatterji, 2009). Resources and 
capabilities are also an important theme for organizational theory. Contributions in this avenue discuss how organizations can build resources and capabilities to succeed in BoP markets. Two articles combine social capital with a discussion of resources and capabilities of the individual and communities (Arora and Romijn 2010, Ansari et al. 2012).

Additionally, some articles address specific literature streams such as micro-credits (Rankin 2001), corporate citizenship (Hahn 2009), competitive dynamics (McIntosh and Wydick 2005), neoliberalism governance (Varman et al. 2012), institutional theory and transaction cost economics (Rivera-Santos et al. 2012), or take a knowledge management perspective (Schuster and Holtbrügge 2012).

The analysis of the selected articles by research method reveals that qualitative research prevails in the form of case studies (24). Most of the articles that are employing this type of research design use a multiple case study approach ranging from 2 to 64 cases, while only three publications rely on a single case study. Even though a comparative research design that explores the differences between successful and less successful BoP initiatives is not usual, three articles follow this approach. Interviews (25) are the main mode for data collection. These are either directly analyzed or all primary data is compiled into case studies, which are then used for analysis. Most case studies are built on less than four interviews. Compiling case studies through multiple interviews with different people in the organization remain a rare exception. Observations (16) are also frequently used, and they generally focus on the consumers. Very few articles use methods such as panel data analysis (2), experiments (1), focus groups (1), testimonies (1) or ethnography (1), where researchers get embedded into the local context. Grounded theory is an often articulated way to approach the data. When it comes to the research duration, most case studies present cross-sectional rather than longitudinal studies. 


\section{In-house and field assumptions}

The analysis of the articles in the BoP relevant research domains led to the in-house assumptions described in this section and summarized in Table

2.

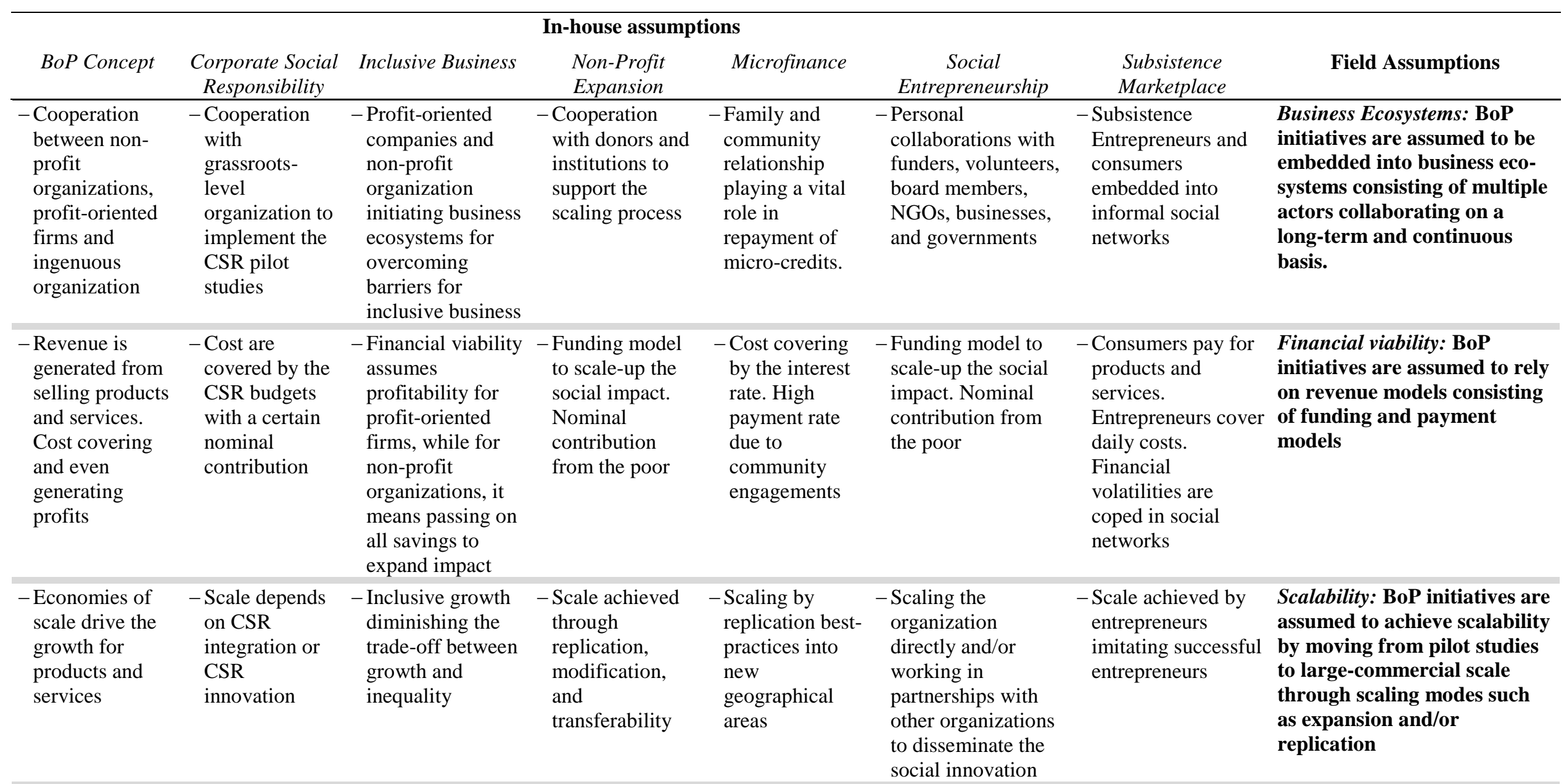




\begin{tabular}{|c|c|c|c|c|c|c|c|}
\hline $\begin{array}{l}\text { - Innovation in } \\
\text { individual } \\
\text { business } \\
\text { activities and on } \\
\text { a business } \\
\text { model level. } \\
\text { Cost } \\
\text { innovations to } \\
\text { break through } \\
\text { the poverty } \\
\text { penalty }\end{array}$ & $\begin{array}{l}\text { - Innovation in } \\
\text { individual } \\
\text { business } \\
\text { activities and } \\
\text { on a business } \\
\text { model level. }\end{array}$ & $\begin{array}{l}\text { - Innovativeness } \\
\text { occurs business } \\
\text { model level, but } \\
\text { also in many } \\
\text { activities ranging } \\
\text { from design, } \\
\text { distribution, } \\
\text { marketing, and } \\
\text { manufacturing }\end{array}$ & $\begin{array}{l}\text { - Innovation on } \\
\text { the operational } \\
\text { model on how to } \\
\text { deliver products } \\
\text { and services }\end{array}$ & $\begin{array}{l}\text { - Innovations in } \\
\text { terms of } \\
\text { individual and } \\
\text { community } \\
\text { lending } \\
\text { schemes. } \\
\text { Competition } \\
\text { with informal } \\
\text { moneylenders }\end{array}$ & $\begin{array}{l}\text { - Social innovations, } \\
\text { new products, } \\
\text { services and } \\
\text { business models } \\
\text { simultaneously } \\
\text { meeting social } \\
\text { needs and creating } \\
\text { new social } \\
\text { relationships }\end{array}$ & $\begin{array}{l}\text { - Innovation in terms } \\
\text { of repackaging for } \\
\text { affordability and } \\
\text { access, } \\
\text { transportation to } \\
\text { remote areas, and } \\
\text { word-of-mouth } \\
\text { promotion }\end{array}$ & $\begin{array}{l}\text { Innovativeness: BoP } \\
\text { initiatives are assumed to } \\
\text { require innovativeness in } \\
\text { terms of cost innovation for } \\
\text { affordability and breaking } \\
\text { the poverty penalty and } \\
\text { innovations in individual } \\
\text { business activities as well as } \\
\text { on a business model level }\end{array}$ \\
\hline $\begin{array}{l}\text { - Low-income } \\
\text { populations } \\
\text { mostly face } \\
\text { financial } \\
\text { constraints }\end{array}$ & $\begin{array}{l}\text { - Low-income } \\
\text { populations } \\
\text { have a wide } \\
\text { range of } \\
\text { different needs. }\end{array}$ & $\begin{array}{l}\text { - Multifaceted } \\
\text { resource } \\
\text { constraints for } \\
\text { individual and } \\
\text { communities }\end{array}$ & $\begin{array}{l}\text { - Poor people } \\
\text { lacking basic } \\
\text { necessities and } \\
\text { multifaceted } \\
\text { research } \\
\text { constrains }\end{array}$ & $\begin{array}{l}\text { - Entrepreneurs } \\
\text { making } \\
\text { conscious } \\
\text { investment } \\
\text { decision to } \\
\text { improve their } \\
\text { income }\end{array}$ & $\begin{array}{l}\text { - Mostly financial } \\
\text { constraints, since } \\
\text { the poor are willing, } \\
\text { but often unable to } \\
\text { pay even a small } \\
\text { part of the price of } \\
\text { the products and } \\
\text { services }\end{array}$ & $\begin{array}{l}\text { - Entrepreneurs and } \\
\text { consumers are } \\
\text { embedded into } \\
\text { cultural-rich arenas } \\
\text { with high } \\
\text { heterogeneity of } \\
\text { preferences and } \\
\text { needs }\end{array}$ & $\begin{array}{l}\text { Resource constraints: BoP } \\
\text { initiatives are assumed to face } \\
\text { multifaceted and } \\
\text { heterogeneous constraints }\end{array}$ \\
\hline $\begin{array}{l}\text { - Poor engaged as } \\
\text { co-inventors or } \\
\text { recipients and } \\
\text { are positioned a } \\
\text { consumers } \\
\text { producers, and } \\
\text { entrepreneurs }\end{array}$ & $\begin{array}{l}\text { - Poor engaged } \\
\text { as co-inventors } \\
\text { or recipient. } \\
\text { Network } \\
\text { positions has a } \\
\text { strong focus on } \\
\text { the poor as } \\
\text { producers, but } \\
\text { also on } \\
\text { consumers and } \\
\text { entrepreneurs }\end{array}$ & $\begin{array}{l}\text { - Poor as being } \\
\text { included in the } \\
\text { value creation as } \\
\text { co-inventors, co- } \\
\text { producers, or } \\
\text { business co- } \\
\text { venturing }\end{array}$ & $\begin{array}{l}\text { - Poor mostly } \\
\text { engaged as } \\
\text { recipients. Poor } \\
\text { are supported as } \\
\text { consumers and } \\
\text { entrepreneurs }\end{array}$ & $\begin{array}{l}\text { - Poor are } \\
\text { entrepreneurs } \\
\text { and engaged in } \\
\text { the customizing } \\
\text { of micro-credits }\end{array}$ & $\begin{array}{l}\text { - Poor as being } \\
\text { passive supplicants } \\
\text { for aid for covering } \\
\text { basic social needs, } \\
\text { such as food, shelter } \\
\text { or education }\end{array}$ & $\begin{array}{l}\text { - Co-production } \\
\text { between } \\
\text { entrepreneurs and } \\
\text { consumers }\end{array}$ & $\begin{array}{l}\text { Role of the Poor: BoP } \\
\text { initiatives assume that the } \\
\text { poor are engaged as co- } \\
\text { inventors or recipients and } \\
\text { are positioned as consumers } \\
\text { producers, and entrepreneurs }\end{array}$ \\
\hline
\end{tabular}

Table 2: In-house and field assumptions 
Corporate Social Responsibility (CSR) assumes that companies should take responsibility for poverty alleviation (Margolis and Walsh 2003). CSR investments pay off through making competitive advantages more sustainable. CSR initiatives mostly involve pilot studies, which can scale-up through CSR integration and/or innovation, going beyond a purely philanthropic effort. CSR integration argues for CSR initiatives to become embedded in the daily business operation of an organization, which implies conducting existing business operations more responsibly. CSR innovation refers to developing new technologies and business models that solve social and environmental problems (Halme and Laurila 2009) including individual business operations as well as more strategic issues. Overall, CSR can serve as a new mechanism for innovation within MNEs, but MNEs need to embed these inventions into regular business operations to reach large-scale commercial success. The CSR literature refers to the low-income segment as "...the poor and marginalized ..." (Blowfield 2005, p. 522) who can play the role of co-inventors as well as recipients of products and services. Since some CSR initiatives aim at sustainable supply chains, the engagement of the poor as consumers, entrepreneurs and particularly as 'producers' is interesting (Jenkins 2005). Inclusive Business captures the richness and creativity among low-income people as a means to support the development of inclusive innovations (George et al. 2012). Inclusive Business enhances social and economic wellbeing through integrating the poor as co-inventors and co-producers (Halme et al. 2012, Mair et al. 2012, Mendoza and Thelen 2008). Instead of revenue models, inclusive business uses the term financial viability. Financial viability assumes attaining profitability for profit-oriented firms and passing on all savings and profits in order to expand their impact for non-profit organizations (George et al. 2012; Mendoza and Thelen 2008). Inclusive business research domain views scalability as inclusive growth, as George et al. (2012, p. 678) argue “...small entrepreneurial firms ... have the motivation to ... implement ideas for inclusive innovation. However, these ventures typically lack the resources needed to scale-up inclusive innovation efforts. In contrast, large multinationals, which possess the 
resources needed frequently lack the motivation needed to do so...”. Barriers to scale result from a lack of resources and capabilities and can be overcome by building business ecosystems and by taking advantage of resources from partners in the inclusive business ecosystem (Gradl and Jenkins 2011). Relationships among the different organizations in the business ecosystem should be stable and long-term. Additionally, business ecosystems should enable an interplay between large and small firms in driving inclusive innovation (George et al. 2012). The term 'inclusive business model' (e.g., Halme et al. 2012) assumes that innovativeness occurs at the business model level, but also in individual activities ranging from design, distribution, marketing, and manufacturing. Halme et al. (2012) also point out the bricolage approach in intra-organizational innovation processes, which is appropriate for navigating through resource-scarce environments. The narrative "...disenfranchised individuals and communities" (George et al. 2012, p. 662) is interpreted as the multifaceted constraints on the individuals' and communities' resource.

Non-Profit Expansion discusses how these organizations scale the impact of their operations (e.g., Bloom and Chatterji 2009, Westley and Antadze, 2010). Scalability comprises replicability, adaptability, and transferability. Replicability is the capacity to reproduce the organizational structures, processes, products or services. Adaptability is the capacity to adjust these elements to a changing socioeconomic context. If the operational model of non-profit organizations displays replicability and adaptability, it has high transferability (Weber et al. 2012). The focus on adaptation and transferability suggests that people in different geographical areas have diverse needs, preferences, and cultures. Thus, resource constraints are most likely to be heterogeneous. Non-profit expansion domain assumes that organizations adapt their operational models if they transfer them from one geographical area to another. The revenue model involves external funding, but also considers that a nominal contribution, or 'service fee' (Uvin and Miller 1996, p. 346), would facilitate the scaling process. The assumption of financial constraints is directly related to the people's low-income. Innovativeness is low, since most 
services address a lack of governmental services. It is also assumed that the scaling process is highly influenced by collaboration with governments, institutions, and communities (Uvin and Miller 1996, p. 346) and, that this process should become increasingly formalized and stable over time. Additionally, it is assumed that the poor are more passive recipients of aid rather than active actors in the value creation.

Microfinance literature emphasizes how the poverty penalty affects the BoP market, where the lack of adequate financial services allows local moneylenders to charge high interest rates. Thus, microfinance services both personal and entrepreneurial, are considered as alternatives to informal moneylenders, aiming to benefit BoP borrowers (McIntosh and Wydick 2005). Within this research domain, innovativeness manifests in the individual and/or grouplending contracts, particularly in the incentives and repayment schedules. Microfinance organizations continuously look for innovative managerial and organizational structures to reduce the costs for providing micro-credits, while maintaining or even increasing outreach (Morduch 1999). Microcredits at the BoP succeed in communities with strong social bindings among their members, who frequently use social capital as a substitute for collateral. Communities therefore benefit from traditional, group-based modes of informal finance, rotating savings and credit associations (Morduch 1999). Family and community networks play a key role in the repayment of microcredits. Microfinance research domain assumes scalability based on increasing the numbers of borrowers (McIntosh and Wydick 2005) through the replication of 'best practices' in new geographical areas. Minor emphasis is placed on extending the scope of financial services in terms of savings and insurance services in existing geographical areas. Even though microcredits address the financial needs of people living below to the poverty line, they are not exclusive of this segment; in fact, borrowers are often clustered above the poverty line. The financial viability of microcredits ranges from selfsustaining to being reliant on donations to subsidize interest rates and mitigate financial risks. Particularly, Microfinance research often uses the concept of deprivation, which considers 
people as being limited in terms of individual financial resources, but rich in terms of entrepreneurial ideas.

Social Entrepreneurship assumes scalability, where “... initial successes often lead to ... requests to scale or replicate ...” (Austin et al. 2006, p. 7). Reaching scale involves expanding the organization directly and/or working in partnerships with other organizations to disseminate the social innovation. This is described by stages such as “... intention formation stage, a startup stage, a growth stage, a consolidation stage..." (Mair and Marti 2006, p. 42). Innovation activities are broad and conceptualized as social innovations. As social innovations, the new products, services and business models simultaneously meet social needs and create new social relationships where poor people can become co-inventors of such social innovations. Social entrepreneurship is open to including poor people as consumers, producers, and/or entrepreneurs, but the dominant role of the poor within the social entrepreneurship domain remains as passive recipients for aid to cover basic social needs, such as food, shelter or education. For the payment model, it is argued that “... 'customers' are willing, [but] often ... unable to pay even a small part of the price of the products and services provided." (Mair and Marti 2006, p. 39). Therefore, financial viability focuses on funding schemes, which include “... fund-raising, grant-writing, selling, and advertising...” (Bloom and Chatterji 2009, p. 122). Social entrepreneurs build network relationships with other individuals, communities, and organizations; therefore, they must be skilled at managing a wide diversity of personal relationships with funders, volunteers, and board members. They work collaboratively with other non-profit organizations, businesses, and governments to attain the critical resources (Austin et al. 2006, Mair and Marti 2006).

The field of Subsistence Marketplaces provides insights into market interactions between entrepreneurs and consumers. It is a bottom-up approach to understanding how people survive in difficult living-conditions (Viswanathan et al. 2012). The role of the poor is as both entrepreneurs and consumers, who are resource-constrained with respect to income and literacy, 
but are network-rich, with stable social ties. Social ties facilitate information sharing and the development of consumer and entrepreneurial skills (Viswanathan et al. 2008). The interaction takes the form of co-invention, where entrepreneurs and consumers collaborate on distribution, pricing, marketing or packaging, but mostly it is dominated by subsistence consumers purchasing products and services, which fulfill their needs. The co-production between entrepreneurs and consumers emerges through repackaging products for affordability and access, transportation to remote areas, and word-of-mouth promotion. Such co-production benefits from the intimate knowledge and social networks of subsistence consumers. These consumers are embedded in cultural-rich arenas, suggesting heterogeneous preferences and needs. Scalability does not arise directly as a narrative. The assumption is that subsistence entrepreneurs remain micro- and small-scale businesses with limited growth potential. The emphasis is on surviving the harsh conditions of subsistence markets. Scaling occurs when others imitate the experiences of successful subsistence entrepreneurs in their social network. Finally, considering the revenue model assumes that subsistence entrepreneurs are selfsustaining having to "... adjust to all the difficulties, profit and loss in the business each day" (Viswanathan et al. 2010, p. 11). Social networks support entrepreneurs in the event of financial volatility. Subsistence consumers pay regular prices and do not benefit from any subsidies or aid contributions.

By comparing in-house assumptions across the different research domains, they can be aggregated into six field assumptions, as shown in the last column in Table 2. First, the Business ecosystems field assumption focuses on how BoP initiatives are supposed to be embedded in business ecosystems consisting of multiple actors collaborating on a long-term and continuous basis. Second, BoP initiatives are assumed to rely on revenue models consisting of funding and payment models, this assumption is called financial viability. Third, scalability assumption focuses on how BoP initiatives achieve growth and augment their impact by moving from pilot studies to large-commercial operations through scaling modes such as expansion and/or 
replication. Fourth, BoP initiatives are assumed to require novel cost schemes for increasing affordability thus, breaking the poverty penalty. It also requires innovation in individual business activities as well as at the business model level; this assumption is labeled as Innovativeness. Fifth, the resource constraints field assumption focuses on the multifaceted and heterogeneous nature of the resource constraints faced by BoP initiatives. Finally, the role of the poor assumption considers that the poor become engaged in BoP initiatives as co-inventors or recipients playing different roles as consumers, producers, and entrepreneurs.

\section{DISCUSSION AND FUTURE RESEARCH}

Our discussion of future research draws upon our descriptive results such as research methods and streams of literature, and our in-house and field assumptions. We structure the discussion of the future research into empirical and theoretical advancements.

\section{Empirical advancements}

Empirical finding 1. Based on the analyzed articles, banking and finance services, rural development, ICT services, non-durable and durable consumer goods dominate the empirical contexts (see Table 1). This might be due to the fact that it is relatively easy to look into the value proposition of a tangible good, as for example, electric lightning, since it offers financial benefits through replacing expensive kerosene lamps.

Empirical recommendation 1.1. More attention should be placed on services, which have long-term, less tangible, and no direct financial benefits such as health, education, water, and sanitation which also challenge the value proposition and value capture as elements of the BoP business model. Water, for example, is a human right, which influences the sentiments around making people pay for water, which can become an obstacle for capturing value. The value proposition of better health through improved sanitation and hygiene can be difficult to understand for BoP consumers. In the sanitation context, value creation in terms of promoting, 
selling, manufacturing, and installing toilets can lead to problems further down in the sanitation chain. Value creation also needs to consider the emptying of as well as the treatment and safe disposal of the fecal sludge.

Empirical recommendation 1.2. Academia should create BoP knowledge on more complex empirical contexts. More complex means that it is more difficult for BoP consumers to understand the benefits of the products and services and/or it is more difficult to provide them. A typical example are sanitation services where BoP consumers tend to underestimate long-term impacts on their health jeopardizing pay-per-use approaches (London and Esper 2014). More complex empirical contexts require more integrative research designs, beyond the cross-sectional approach. Empirical advancement should go towards more longitudinal studies, ethnographic methods, and data triangulation. The call for more longitudinal studies is rational, since BoP initiatives take time until they can be considered successful or not. More longitudinal studies would also allow compiling case studies on richer interview data in terms of number of interviews and variety of organizational functions.

Empirical finding 2. Most of the cases are reported as successful BoP initiatives, with only three research designs using a comparative study on successful and less successful initiatives. This suggests a certain bias in the findings.

Empirical recommendation 2.1. Empirical advancements should look into the less successful initiatives and failures to build a stronger theoretical argument on how to succeed in BoP markets.

Empirical finding 3. As highlighted in the evaluation of business ecosystems, most case studies investigate formal organizations. Little attention is drawn on informal businesses and networks and on understanding their role within the BoP, despite the fact that low-income contexts are in tendency strongly characterized by informality.

Empirical recommendation 3.1. Empirically, we need suitable research methods such as those mentioned in recommendation 1.2 to study more informal businesses and networks to 
provide insights and guidance on how organizations can adequately engage BoP entrepreneurs as business partners.

Empirical finding 4. Most data is currently obtained through interviews with key informants from the organizations starting the BoP initiative.

Empirical recommendation 4.1. It would be interesting to obtain more information from the communities that are involved and the individual households to triangulate the data. Ethnographic methods would allow researchers to take advantage of being embedded in the actual context. Varman et al. (2012) make a strong argument and provide a clear illustration for the need of this type of data triangulation. Such a triangulation of the data should inform a rigorous assessment of social, economic, and environmental output, outcome, and impact.

Empirical finding 5. As highlighted in Table 1, the non-profit organizations, social entrepreneurs, and profit-oriented companies took advantage of BoP concept, but little is known about the ways in which these organizations are able to cope with BoP-specific challenges thanks to the insights of BoP research.

Empirical recommendation 5.1. It would be interesting to have comparative studies on how these different types of organizations implement the certain elements of the BoP concept.

\section{Theoretical advancements}

By comparing in-house assumptions across the different research domains, they can be aggregated into six field assumptions leading to theoretical findings which serve as foundation to develop some theoretical recommendations and research questions (see Table 3).

Theoretical findings $1 \& 2$. First, the Business ecosystems field assumption focuses on how BoP initiatives are supposed to be embedded in business ecosystems consisting of multiple actors collaborating on a long-term and continuous basis. Second, BoP initiatives are assumed to rely on revenue models consisting of funding and payment models, this assumption is called financial viability. 
Theoretical recommendation 1.1. Reflections on financial viability should provide a stronger foundation of value capturing across different income levels and marketing strategies for the expansion in the scaling process. Research should investigate, among others, the following questions: How should necessary (local) investments into the scaling process be integrated into financial viability? How does financial viability depend on covering different income levels? How does value capture across different income levels influences the business model evolution? How do marketing strategies for expanding the business scope create rebound effects with the financial viability?

Theoretical finding 3. Third, scalability assumption focuses on how BoP initiatives achieve growth and augment their impact by moving from pilot studies to large-commercial operations through scaling modes such as expansion and/or replication.

Theoretical recommendation 3.1. Our results on the scalability field assumption suggest that replication is the main mode for achieving large-scale impact, but the previous replication is rarely little more than the exploitation of a simple business and/or operational formula. Theoretical advancements should focus on the learning process to uncover and develop the most suitable business model as well as the ongoing assessment that precedes large-scale replication of it. Future research should explore, among other questions: How can organizations develop replication capabilities in BoP markets? How does causal ambiguity influence the learning processes leading the replication capability?

Theoretical finding 4. Fourth, BoP initiatives are assumed to require novel cost schemes for increasing affordability thus, breaking the poverty penalty. It also requires innovation in individual business activities as well as at the business model level; this assumption is labeled as Innovativeness.

Theoretical recommendation 4.1. We propose that future research should investigate the value capture aspect of the funding schemes and the consistency of the business model elements during the business model evolution. For example: How can organizations be innovative in 
capturing value through external funding? How can organizations innovate value creation to let the poor become co-producers and co-inventors? How can organizations innovate value propositions for more complex poverty needs?

Theoretical findings 5 \& $\mathbf{6}$. Fifth, the resource constraints field assumption focuses on the multifaceted and heterogeneous nature of the resource constraints faced by BoP initiatives. Finally, the role of the poor assumption considers that the poor become engaged in BoP initiatives as co-inventors or recipients playing different roles as consumers, producers, and entrepreneurs.

Theoretical recommendation 5.1. Considering the resource constraint field assumption we propose that research needs to depart from the perspective that BoP markets consist mostly of financial resource constraints to explore its multifaceted and heterogeneous nature. We suggest that future research should use learning theories, especially, transformative learning processes, which could explain how organizations can understand poverty as a multifaceted and heterogeneous constraint. Future research should consider, for instance: How do cognitive structures influence individual's perception on resource constraints in BoP markets? How can transformative learning processes break-apart from these cognitive structures? How can combinative capabilities facilitate transformative learning processes?

\begin{tabular}{|c|c|c|}
\hline $\begin{array}{l}\text { Area of } \\
\text { research }\end{array}$ & Focus & Research questions \\
\hline \multicolumn{3}{|c|}{ Theoretical findings $1 \& 2$} \\
\hline $\begin{array}{l}\text { Business } \\
\text { Ecosystems } \\
\text { and financial } \\
\text { viability }\end{array}$ & $\begin{array}{l}\text { Reflecting on financial } \\
\text { viability should provide a } \\
\text { stronger foundation of value } \\
\text { capturing for multiple actors } \\
\text { across different income } \\
\text { levels participating in the } \\
\text { scaling process at the BoP. }\end{array}$ & $\begin{array}{l}\text { - How should necessary (local) } \\
\text { investments into the scaling process be } \\
\text { integrated into financial viability? } \\
\text { - How does financial viability depend on } \\
\text { covering different income levels? } \\
\text { - How does value capture across different } \\
\text { income levels influences the business } \\
\text { model evolution? } \\
\text { - How do marketing strategies for } \\
\text { expanding the business scope create } \\
\text { rebound effects with the financial } \\
\text { viability? }\end{array}$ \\
\hline
\end{tabular}




\begin{tabular}{|c|c|c|}
\hline \multicolumn{3}{|c|}{ Theoretical finding 3} \\
\hline Scalability & $\begin{array}{l}\text { Exploring the learning } \\
\text { process of BoP initiatives } \\
\text { should provide insights to } \\
\text { uncover and develop suitable } \\
\text { business models enabling } \\
\text { scaling modes such as } \\
\text { expansion and/or replication. }\end{array}$ & $\begin{array}{l}\text { - How can organizations develop } \\
\text { replication capabilities in BoP markets? } \\
\text { - How does causal ambiguity influence } \\
\text { the learning processes leading the } \\
\text { replication capability? }\end{array}$ \\
\hline \multicolumn{3}{|c|}{ Theoretical finding 4} \\
\hline Innovativeness & $\begin{array}{l}\text { Investigating value capture in } \\
\text { novel business activities and } \\
\text { business models within BoP } \\
\text { should provide insights to } \\
\text { develop atypical financial } \\
\text { schemes (costs and funding) } \\
\text { for increasing affordability. }\end{array}$ & $\begin{array}{l}\text { - How can organizations be innovative in } \\
\text { capturing value through external } \\
\text { funding? } \\
\text { - How can organizations innovate value } \\
\text { creation to let the poor become co- } \\
\text { producers and co-inventors? } \\
\text { - How can organizations innovate value } \\
\text { propositions for more complex poverty } \\
\text { needs? }\end{array}$ \\
\hline \multicolumn{3}{|c|}{ Theoretical findings $5 \& 6$} \\
\hline $\begin{array}{l}\text { Resource } \\
\text { constraints } \\
\text { and role of the } \\
\text { poor }\end{array}$ & $\begin{array}{l}\text { A more integrative approach } \\
\text { regarding poverty and } \\
\text { resource constraints in BoP } \\
\text { markets, beyond economic } \\
\text { factors, should shed light to } \\
\text { better understand the } \\
\text { different engagement roles of } \\
\text { the poor. }\end{array}$ & $\begin{array}{l}\text { - How do cognitive structures influence } \\
\text { individual's perception on resource } \\
\text { constraints in BoP markets? } \\
\text { - How can transformative learning } \\
\text { processes break-apart from these } \\
\text { cognitive structures? } \\
\text { - How can combinative capabilities } \\
\text { facilitate transformative learning } \\
\text { processes? }\end{array}$ \\
\hline
\end{tabular}

Table 3: Research Agenda for the BoP concept

\section{CONCLUSION}

Our literature review and analysis face some limitations. Although the future theoretical and empirical advancements presented in this article were discussed with competent academics and practitioners, the representativeness of our results is limited to a certain degree due to the interests and expertise of individual researchers which may represent biases. Although these limitations must be kept in mind, we are confident that our findings provide new insights for academics.

We extended previous literature reviews by considering the latest publications up to the end of 2014. Our descriptive analysis indicates that the practitioner journals still play a vital role in legitimizing the BoP debate. The academic discussion is still not strongly embedded in 
research institutions from low-income countries. We showed that our research domains have consistent in-house assumptions, which therefore can be aggregated into six general field assumptions: business ecosystems, financial viability, innovativeness, resource constraints, role of the poor and scalability. Future research could have a more fine-grained view of the inhouse and field assumptions. Instead of focusing on the similarities, future research can also look more closely into the differences in the in-house assumption among different domains.

Our theoretical advancements and research questions suggest following common themes for future research. First, learning processes arise as a common theme in advancing the BoP concept. It is linked to the empirical recommendations for more longitudinal studies, since such learning processes and their impact on resource constraints, replication and other factors can only be observed over a longer period of time. Investigating learning processes are associated with the need of comparative studies, in which organizations can be compared according the learning processes and the success of the BoP initiatives. Theoretically, it means that there would be a much stronger theoretical grounding in learning theories. We suggest absorptive capacity, especially transformative learning processes, as a promising theoretical grounding. Learning processes are difficult to observe and BoP research has to find adequate research approaches to investigate them in detail. Another common theme in advancing the BoP concept is business model innovation. Previous research has highlighted the need to open up business models to accommodate economic and social goals, classify corporate-NGO business models, and provide empirical evidence for pay-per-use business models. In addition, we suggest future theoretical advancements in replication of complex business models, business model evolution, and consistency in the business model configuration.

A final common theme arises from achieving financial viability through tapping into higher income segments. Since the early stages of the BoP concept, BoP markets have been argued to require other strategies than traditional transnational approaches such as global 
integration and local responsiveness. BoP markets require a new mix of capabilities. The BoP concept has evolved into a relatively separate research field within the international management. In the context of financial viability, the combination of BoP markets and the emerging middle-income segment suggest linking the BoP discussion to traditional research in international management more closely. However, this link does not mean that the BoP concept is only a topic for international management scholars. On the contrary, the BoP concept benefits from research efforts in other domains including but not limited to Corporate Social Responsibility, Inclusive Business, Microfinance, Social Entrepreneurship, Subsistence Marketplaces and Non-Profit Expansion. Whereas, Entrepreneurship Studies about formal and informal businesses in low-income countries can be an interesting domain to further extend the BoP concept.

Overall, these three common themes suggest a more theoretical-driven approach. Such an approach would be more in line with the argument that theories derived from industrialized markets are not applicable in the same way to BoP markets. Our common themes of learning processes, business model innovation, and the link between BoP markets and emerging middleincome segment do not only advance the BoP concept, but management theories in general. Our findings have also implication for stakeholders. Our suggested theoretical advancements for replication are, for example, interesting for development banks, which currently look for successful replication strategies. 


\section{REFERENCES}

Alvesson, M., and Sandberg, J. (2011). Generating research questions through problematization. Academy of Management Review, 36(2), 247-271.

Amin, M. and Mabe, M. (2000). Impact factors: use and abuse. Perspectives in Publishing, $1(1), 1-6$.

Ansari, S., Munir, K., and Gregg, T. (2012). Impact at the 'bottom of the pyramid': The role of social capital in capability development and community empowerment. Journal of Management Studies, 49(4), 813-842.

Archambault, E. and Larivière, V. (2010). The limits of bibliometrics for the analysis of the social sciences and humanities literature. World Social Science Report 2010: Knowledge divides. Chapter 7, UNESCO, 251-254.

Arnould, E. and Mohr, J. (2005). Dynamic Transformations for the Base-of-the-Pyramid Market Clusters. Journal of the Academy of Marketing Science, 33(3), 254-274.

Arora, S., and Romijn, H. (2012). The empty rhetoric of poverty reduction at the base of the pyramid. Organization, 19(4), 481-505.

Austin, J., Stevenson, H., and Wei-Skillern, J. (2006). Social and commercial entrepreneurship: same, different, or both?. Entrepreneurship Theory and Practice, 30(1), 1-22.

Bloom, P. N., and Chatterji, A. K. (2009). Scaling social entrepreneurial impact. California Management Review, 51(3), 114-133.

Blowfield, M. (2005). Corporate social responsibility: reinventing the meaning of development?. International Affairs, 81(3), 515-524.

Bruton, G. (2010). Business and the worlds poorest billion the need for an expanded examination by management scholars. Academy of Management Perspectives. 34(3), 6-10.

Burgess, S. M., and Steenkamp, J. B. E. (2006). Marketing renaissance: How research in emerging markets advances marketing science and practice. International Journal of Research in Marketing, 23(4), 337-356.

Cañeque, F.C. and Hart, S.L. (2015). Base of the Pyramid 3.0. Greenleaf Publishing.

Chesbrough, H., Ahern, S., Finn, M. and Guerraz, S. (2006): Business Model for Technology in the Developing World: The Role of Non-Governmental Organizations. California Management Review, 48(3), 48-61.

Chikweche, T., and Fletcher, R. (2010). Understanding factors that influence purchases in subsistence markets. Journal of Business Research, 63(6), 643-650. 
Cipolla, C., and Reynoso, J. (2017). Service Design as a sensemaking activity: Insights from low-income communities in Latin America, in D. Sangiorni and A. Prendiville (Eds.), Designing for Service - Key Issues and New Directions, Bloomsbury Publishing, 147-162.

Clyde. P. and Karnani, A. (2015): Improving Private Sector Impact on Poverty Alleviation. California Management Review, 57(2), 20-35.

Dembek, K., Sivasubramaniam, N., and Chmielewski, D. A. (2019). A Systematic Review of the Bottom/Base of the Pyramid Literature: Cumulative Evidence and Future Directions. Journal of Business Ethics, 1-18.

Financial Times Lexicon (2017). Definition of bottom of the pyramid (BOP). [ONLINE] Available at: http://lexicon.ft.com/Term?term=bottom-of-the-pyramid-(bop). [Accessed 15 February 2019].

Fisk, R.P., Anderson, L., Bowen, D.E., Gruber, T., Ostrom, A., Patricio, L., Reynoso, J., and Sebastiani, R. (2016). Billions of impoverished people deserve to be better served: A call to action for the service research community. Journal of Service Management, 27(1), 43-55.

Gebauer, H., Haldimann, M. and Saul, C. J. (2017). Business model innovations for overcoming barriers in the base-of-the-pyramid market. Industry and Innovation, 24(5), 543-568.

Gebauer, H. and Reynoso, J. (2013). An agenda for service research at the base of the pyramid. Journal of Service Mangement, 24(5), 482-502.

George, G., McGahan, A. M., and Prabhu, J. (2012). Innovation for inclusive growth: Towards a theoretical framework and a research agenda. Journal of Management Studies, 49(4), 661683.

Gradl, C., and Jenkins, B. (2011). Tackling barriers to scale: From inclusive business models to inclusive business ecosystems. The CSR initiative at the Harvard Kennedy school.

Halme, M., and Laurila, J. (2009). Philanthropy, integration or innovation? Exploring the financial and societal outcomes of different types of corporate responsibility. Journal of Business Ethics, 84(3), 325-339.

Halme, M., Lindeman, S., and Linna, P. (2012). Innovation for Inclusive Business: Intrapreneurial bricolage in multinational corporations. Journal of Management Studies, 49(4), 743-784.

Hahn, R. (2009). The ethical rational of business for the poor-integrating the concepts bottom of the pyramid, sustainable development, and corporate citizenship. Journal of Business Ethics, 84(3), 313-324.

Jenkins, R. (2005). Globalization, corporate social responsibility and poverty. International Affairs, 81(3), 525-540. 
Karnani, A. (2007). The mirage of marketing to the Bottom of the Pyramid: How the private sector can help alleviate poverty. California Management Review, 49(4), 90-111.

Karnani, A. (2009). Romanticising the poor harms the poor. Journal of International Development. 21(1), 76-86.

Kolk, A., Rivera-Santos, M., and Rufin, C. (2014). Reviewing a decade of research on the "Base/Bottom of the Pyramid" (BOP) concept. Business and Society, 53(3), 338-377.

Kuhn, T. S. (2003). Die Struktur wissenschaftlicher Revolutionen. Frankfurt am Main: Suhrkamp.

London, T., Anupindi, R., and Sheth, S. (2010). Creating mutual value: Lessons learned from ventures serving Base of the Pyramid producers. Journal of Business Research, 63(6), 582594.

London, T., and Esper, H. (2014). Assessing poverty-alleviation outcomes of an enterprise-led approach to sanitation. Annals of the New York Academy of Sciences, 1331(1), 90-105.

London, T., and Hart, S. L. (2010). Next generation business strategies for the Base of the Pyramid: New approaches for building mutual value. Upper Saddle River, NJ: Pearson Education.

Mair, J., \& Marti, I. (2006). Social entrepreneurship research: A source of explanation, prediction, and delight. Journal of World Business, 41(1), 36-44.

Mair, J., and Marti, I. (2009). Entrepreneurship in and around institutional voids: A case study from Bangladesh. Journal of Business Venturing, 24(5), 419-435.

Mair, J., Marti, I., and Ventresca, M. J. (2012). Building inclusive markets in rural Bangladesh: How intermediaries work institutional voids. Academy of Management Journal, 55(4), 819850.

Martin, K. D., and Hill, R. P. (2015). Saving and well-being at the base of the pyramid: Implications for transformative financial services delivery. Journal of Service Research, $18(3), 405-421$.

Mayoux, L. (2001). Tackling the down side: Social capital, women's empowerment and microfinance in Cameroon. Development and Change, 32(3), 435-464.

McIntosh, C., and Wydick, B. (2005). Competition and microfinance. Journal of Development Economics, 78(2), 271-298.

Mendoza, R. U. (2011). Why do the poor pay more? Exploring the poverty penalty concept. Journal of International Development, 23(1), 1-28.

Mendoza, R. U., and Thelen, N. (2008). Innovations to make markets more inclusive for the poor. Development Policy Review, 26(4), 427-458. 
Moed, H.F. (2005). Citation analysis in research evaluation. Dordrecht: Springer.

Morduch, J. (1999). The microfinance promise. Journal of Economic Literature, 37(4), 15691614.

Nerur, S. P., Rasheed, A. A., \& Natarajan, V. (2008). The intellectual structure of the strategic management field: An author co-citation analysis. Strategic Management Journal, 29(3), 319-336.

Ostrom, A., Parasuraman, A., Bowen, D.E., Patricio, L., and Voss, C.A. (2015). Service research priorities in a rapidly changing context. Journal of Service Research, 18(2), 127159.

Peirce, C. S. (1994). Collected papers of Charles Sanders Peirce. (C. Hartshorne and P. Weiss, Eds.). Cambridge; MA: Belknap Press of Harvard University Press.

Perez-Aleman, P., and Sandilands, M. (2008). Building value at the top and the bottom of the global supply chain: MNC-NGO partnerships. California Management Review, 51(1), 2449.

Perreault W., and Leigh, L. (1989). Reliability of nominal data based on qualitative judgments. Journal of Marketing Research, 26(2), 135-148.

Polak, P. (2013). The Business Solution to Poverty: Designing Products and Services for Three Billion New Customers. Berrett-Koehler Publishers.

Prahalad, C. K. (2004). The Fortune at the Bottom of the Pyramid. Upper Saddle River, NJ: Pearson Education.

Prahalad, C. K. (2012). Bottom of the Pyramid as a Source of Breakthrough Innovations. Journal of Product Innovation Management, 29(1), 6-12.

Prahalad, C. K., and Hammond, A. (2002). Serving the world's poor, profitably. Harvard Business Review, 80(9), 4-11.

Prahalad, C. K., and Hart, S. L. (2002). The fortune at the bottom of the pyramid. Strategy and Business, Issue 26, 1-14.

Rankin, K. N. (2001). Governing development: neoliberalism, microcredit, and rational economic woman. Economy and Society, 30(1), 18-37.

Rankin, K. N. (2002). Social capital, microfinance, and the politics of development. Feminist Economics, 8(1), 1-24.

Reficco, E., and Gutierrez, R. (2016). Organizational ambidexterity and the elusive quest for successful implementation of BoP ventures. Organization \& Environment, 29(4), 461-485.

Reynoso, J. (1999). Progress and prospects of services management in Latin America. International Journal of Service Industry Management, 10(5), 401-408. 
Reynoso, J., Valdes A., and Cabrera, K. (2015). Breaking new ground: base-of-pyramid service research. The Service Industries Journal, 35(13), 695-709.

Rivera-Santos, M., Rufin, C., and Kolk, A. (2012). Bridging the institutional divide: Partnerships in subsistence markets. Journal of Business Research, 65(12), 1721-1727.

Rubalcaba, L., Lagunes, H., \& Reynoso, J. (2018). Service Innovation in Developing Economies. In F. Gallouj \& F. Djellal (Eds.), A Research Agenda for Service Innovation (pp. 68-84). Edward Elgar Publishing Limited.

Rust, R.T., and Cooil, B. (1994). Reliability measures for qualitative data: theory and implications. Journal of Marketing Research, 31(1), 1-14.

Sanchez, C. M., and Schmid, A. S. (2013). Base of the pyramid success: a relational view. South Asian Journal of Global Business Research, 2(1), 59-81.

Schaefers, T., Moser, R., and Narayanamurthy, G. (2018). Access-based services for the base of the pyramid. Journal of Service Research, 21(4), 421-437.

Schuster, T., and Holtbrügge, D. (2012). Market entry of multinational companies in markets at the bottom of the pyramid: A learning perspective. International Business Review, 21(5), 817-830.

Seelos, C., and Mair, J. (2007). Profitable business models and market creation in the context of deep poverty: A strategic view. Academy of Management Perspectives, 21(4), 49-63.

Simanis, E., and Hart, S. (2008). The Base of the Pyramid Protocol: Toward Next Generation BoP Strategy, 2nd ed. Ithaca: Cornell University.

Uvin, P., and Miller, D. (1996). Paths to scaling-up: alternative strategies for local nongovernmental organizations. Human Organization, 55(3), 344.

Vachani, S., \& Smith, N. C. (2008). Socially responsible distribution: distribution strategies for reaching the bottom of the pyramid. California Management Review, 50(2), 52-84.

Varman, R., Skalén, R., and Belk, R. (2012). Conflicts at the Bottom of the Pyramid: Profiatbility, Poverty Alleviation, and Neoliberal Governmentality. Journal of Public Policy and Marketing, 31(1), 19-35.

Viswanathan, M., Gajendiran, S., \& Venkatesan, R. (2008). Understanding and enabling marketplace literacy in subsistence contexts: The development of a consumer and entrepreneurial literacy educational program in South India. International Journal of Educational Development, 28(3), 300-319.

Viswanathan, M., Rosa, J. A., \& Ruth, J. A. (2010). Exchanges in marketing systems: the case of subsistence consumer-merchants in Chennai, India. Journal of Marketing, 74(3), 1-17. 
Viswanathan, M., Sridharan, S., Ritchie, R., Venugopal, S., \& Jung, K. (2012). Marketing interactions in subsistence marketplaces: A bottom-up approach to designing public policy. Journal of Public Policy \& Marketing, 31(2), 159-177.

Ware, M. and Mabe, M. (2015). The STM Report: An overview of scientific and scholarly journal publishing. Fourth Edition. The Hague: International Association of Scientific, Technical and Medical Publishers, p.60.

Weber, C., Kröger, A., \& Lambrich, K. (2012). Scaling social enterprises-a theoretically grounded framework. Frontiers of Entrepreneurship Research, 32(19), 3.

Westley, F., and Antadze, N. (2010). Making a difference: Strategies for scaling social innovation for greater impact. Innovation Journal, 15(2), pp. 1-19.

World Resources Institute. (2007). The next 4 billion: Market size and business strategy at the base of the pyramid. World Resources Institute, International Finance Corporation. 


\section{Appendix A.}

Table A1. Overview of articles used in the analysis. ${ }^{\mathrm{i}}$

\begin{tabular}{|c|c|c|c|c|c|}
\hline Authors & Title & Year & Source title & Domain & Cited by \\
\hline Margolis \& Walsh. & Misery Loves Companies: Rethinking Social Initiatives by Business & 2003 & Administrative Science Quarterly & CSR & 1078 \\
\hline Jamali \& Mirshak & Corporate Social Responsibility (CSR): Theory and practice in a developing country context & 2007 & Journal of Business Ethics & CSR & 144 \\
\hline Blowfield & Corporate Social Responsibility: Reinventing the meaning of development? & 2005 & International Affairs & CSR & 98 \\
\hline Newell & Citizenship, accountability and community: The limits of the CSR agenda & 2005 & International Affairs & CSR & 97 \\
\hline Jenkins & Globalization, Corporate Social Responsibility and poverty & 2005 & International Affairs & CSR & 95 \\
\hline Prieto-Carron et al. & $\begin{array}{l}\text { Critical perspectives on CSR and development: What we know, what we don't know, and what we need to } \\
\text { know }\end{array}$ & 2006 & International Affairs & CSR & 81 \\
\hline Fox & Corporate social responsibility and development: In quest of an agenda & 2004 & Development & CSR & 63 \\
\hline Newell \& Frynas & Beyond CSR? Business, poverty and social justice: An introduction & 2007 & Third World Quarterly & CSR & 62 \\
\hline Blowfield & Reasons to be cheerful? What we know about CSR's impact & 2007 & Third World Quarterly & CSR & 57 \\
\hline Luetkenhorst & $\begin{array}{l}\text { Corporate social responsibility and the development agenda - The case for actively involving small and } \\
\text { medium enterprises }\end{array}$ & 2004 & Intereconomics & CSR & 52 \\
\hline Dobers \& Halme & Corporate social responsibility and developing countries & 2009 & $\begin{array}{l}\text { Corporate Social Responsibility and } \\
\text { Environmental Management }\end{array}$ & CSR & 43 \\
\hline Halme \& Laurila & $\begin{array}{l}\text { Philanthropy, integration or innovation? Exploring the financial and societal outcomes of different types } \\
\text { of corporate responsibility }\end{array}$ & 2009 & Journal of Business Ethics & CSR & 39 \\
\hline Frynas & Corporate social responsibility and international development: Critical assessment & 2008 & Corporate Governance & CSR & 35 \\
\hline Frynas & $\begin{array}{l}\text { The false developmental promise of Corporate Social Responsibility: Evidence from multinational oil } \\
\text { companies }\end{array}$ & 2005 & International Affairs & CSR & 34 \\
\hline Azmat \& Samaratunge & Responsible entrepreneurship in developing countries: Understanding the realities and complexities & 2009 & Journal of Business Ethics & CSR & 25 \\
\hline George et al. & Innovation for Inclusive Growth: Towards a Theoretical Framework and a Research Agenda & 2012 & Journal of Management Studies & IB & 29 \\
\hline Halme et al. & Innovation for Inclusive Business: Intrapreneurial Bricolage in Multinational Corporations & 2012 & Journal of Management Studies & IB & 21 \\
\hline Mair et al. & Building inclusive markets in rural Bangladesh: How intermediaries work institutional voids & 2012 & Academy of Management Journal & IB & 41 \\
\hline Mendoza \& Thelen & Innovations to make markets more inclusive for the poor & 2008 & Development Policy Review & IB & 26 \\
\hline Hall et al. & $\begin{array}{l}\text { Entrepreneurship and innovation at the base of the Pyramid: A recipe for inclusive growth or social } \\
\text { exclusion? }\end{array}$ & 2012 & Journal of Management Studies & IB & 20 \\
\hline Battilana \& Dorado & Building sustainable hybrid organizations: The case of commercial microfinance organizations & 2010 & Academy of Management Journal & MFI & 145 \\
\hline de Mel et al. & Measuring microenterprise profits: Must we ask how the sausage is made? & 2009 & Journal of Development Economics & MFI & 55 \\
\hline Kabeer & Conflicts over credit: Re-evaluating the empowerment potential of loans to women in rural Bangladesh & 2001 & World Development & MFI & 199 \\
\hline Khandker & Microfinance and poverty: Evidence using panel data from Bangladesh & 2005 & World Bank Economic Review & MFI & 154 \\
\hline
\end{tabular}




\begin{tabular}{|c|c|c|c|c|c|}
\hline Mayoux & Tackling the down side: Social capital, women's empowerment and micro-finance in Cameroon & 2001 & Development and Change & MFI & 133 \\
\hline McIntosh \& Wydick & Competition and microfinance & 2005 & Journal of Development Economics & MFI & 62 \\
\hline Morduch & The microfinance promise & 1999 & Journal of Economic Literature & MFI & 516 \\
\hline Morduch & The microfinance schism & 2000 & World Development & MFI & 190 \\
\hline Pitt \& Khandker & $\begin{array}{l}\text { The impact of group-based credit programs on poor households in Bangladesh: Does the gender of } \\
\text { participants matter? }\end{array}$ & 1998 & Journal of Political Economy & MFI & 330 \\
\hline Rankin & Governing development: Neoliberalism, microcredit, and rational economic woman & 2001 & Economy and Society & MFI & 171 \\
\hline Rankin & Social capital, microfinance, and the politics of development & 2002 & Feminist Economics & MFI & 125 \\
\hline Kistruck et al. & Mitigating principal-agent problems in base-of-the-pyramid markets: An identity spillover perspective & 2013 & Academy of Management Journal & BoP & 10 \\
\hline Cross \& Street & Anthropology at the bottom of the pyramid & 2009 & Anthropology Today & BoP & 22 \\
\hline Martinez \& Carbonell & Value at the bottom of the pyramid & 2007 & Business Strategy Review & $\mathrm{BoP}$ & 10 \\
\hline Chesbrough et al. & Business models for technology in the developing world: The role of non-governmental organizations & 2006 & California Management Review & BoP & 34 \\
\hline Karnani & The mirage of marketing to the bottom of the pyramid: How the private sector can help alleviate poverty & 2007 & California Management Review & BoP & 179 \\
\hline $\begin{array}{l}\text { Perez-Aleman \& } \\
\text { Sandilands }\end{array}$ & Building value at the top and the bottom of the global supply chain: $M N C-N G O$ partnerships & 2008 & California Management Review & BoP & 33 \\
\hline Vachani \& Smith & Socially responsible distribution: Distribution strategies for reaching the bottom of the pyramid & 2008 & California Management Review & BoP & 44 \\
\hline Schwittay & The marketization of poverty & 2011 & Current Anthropology & BoP & 15 \\
\hline Kistruck et al. & $\begin{array}{l}\text { Microfranchising in Base-of-the-Pyramid Markets: Institutional Challenges and Adaptations to the } \\
\text { Franchise Model }\end{array}$ & 2011 & Entrepreneurship: Theory and Practice & $\mathrm{BoP}$ & 17 \\
\hline Webb et al. & $\begin{array}{l}\text { The entrepreneurship process in base of the pyramid markets: The case of multinational } \\
\text { enterprise/nongovernment organization alliances }\end{array}$ & 2010 & Entrepreneurship: Theory and Practice & BoP & 57 \\
\hline Sanchez \& Ricart & Business model innovation and sources of value creation in low-income markets & 2010 & European Management Review & BoP & 16 \\
\hline Akula & Business basics at the base of the pyramid & 2008 & Harvard Business Review & BoP & 23 \\
\hline Karamchandani et al. & The globe: Is the bottom of the pyramid really for you? & 2011 & Harvard Business Review & BoP & 19 \\
\hline London & Making better investments at the base of the pyramid & 2009 & Harvard Business Review & BoP & 49 \\
\hline Prahalad \& Hammond & Serving the world's poor, profitably & 2002 & Harvard Business Review & BoP & 361 \\
\hline Kuriyan et al. & $\begin{array}{l}\text { Information and communication technologies for development: The bottom of the pyramid model in } \\
\text { practice }\end{array}$ & 2008 & Information Society & BoP & 39 \\
\hline Rivera-Santos \& Rufin & Global village vs. small town: Understanding networks at the Base of the Pyramid & 2010 & International Business Review & BoP & 33 \\
\hline Schuster \& Holtbrügge & Market entry of multinational companies in markets at the bottom of the pyramid: A learning perspective & 2012 & International Business Review & BoP & 11 \\
\hline Hahn & $\begin{array}{l}\text { The ethical rational of business for the poor - Integrating the concepts bottom of the Pyramid, sustainable } \\
\text { development, and corporate citizenship }\end{array}$ & 2009 & Journal of Business Ethics & BoP & 32 \\
\hline London et al. & Creating mutual value: Lessons learned from ventures serving base of the pyramid producers & 2010 & Journal of Business Research & BoP & 55 \\
\hline Anderson \& Billou & Serving the world's poor: Innovation at the base of the economic pyramid & 2007 & Journal of Business Strategy & $\mathrm{BoP}$ & 46 \\
\hline
\end{tabular}




\begin{tabular}{|c|c|c|c|c|c|}
\hline Guesalaga \& Marshall & Purchasing power at the bottom of the pyramid: Differences across geographic regions and income tiers & 2008 & Journal of Consumer Marketing & $\mathrm{BoP}$ & 14 \\
\hline Ireland & Lessons for successful BOP marketing from Caracas' slums & 2008 & Journal of Consumer Marketing & $\mathrm{BoP}$ & 16 \\
\hline Waeyenberg \& Hens & Crossing the bridge to poverty, with low-cost cars & 2008 & Journal of Consumer Marketing & $\mathrm{BoP}$ & 15 \\
\hline Wood et al. & $\begin{array}{l}\text { Successful marketing by multinational firms to the bottom of the pyramid: Connecting share of heart, } \\
\text { global "umbrella brands", and responsible marketing }\end{array}$ & 2008 & Journal of Consumer Marketing & $\mathrm{BoP}$ & 16 \\
\hline London \& Hart & Reinventing strategies for emerging markets: Beyond the transnational model & 2004 & Journal of International Business Studies & $\mathrm{BoP}$ & 333 \\
\hline Karnani & Romanticising the poor harms the poor & 2009 & Journal of International Development & $\mathrm{BoP}$ & 15 \\
\hline Ansari et al. & $\begin{array}{l}\text { Impact at the 'Bottom of the Pyramid': The role of social capital in capability development and community } \\
\text { empowerment }\end{array}$ & 2012 & Journal of Management Studies & $\mathrm{BoP}$ & 24 \\
\hline Rashid et al. & $\begin{array}{l}\text { Making profit to solve development problems: The case of telenor as and the village phone programme in } \\
\text { Bangladesh }\end{array}$ & 2009 & Journal of Marketing Management & $\mathrm{BoP}$ & 11 \\
\hline Varman et al. & Conflicts at the bottom of the pyramid: Profitability, poverty alleviation, and neoliberal governmentality & 2012 & Journal of Public Policy and Marketing & $\mathrm{BoP}$ & 11 \\
\hline Arnould \& Mohr & Dynamic transformations for base-of-the-pyramid market clusters & 2005 & $\begin{array}{l}\text { Journal of the Academy of Marketing } \\
\text { Science }\end{array}$ & $\mathrm{BoP}$ & 43 \\
\hline Anderson \& Markides & Strategic innovation at the base of the pyramid & 2007 & MIT Sloan Management Review & $\mathrm{BoP}$ & 71 \\
\hline Hart \& Christensen & The great leap: Driving innovation from the base of the pyramid & 2002 & MIT Sloan Management Review & BoP & 163 \\
\hline Zainudeen et al. & Who's got the phone? gender and the use of the telephone at the bottom of the pyramid & 2010 & New Media and Society & $\mathrm{BoP}$ & 12 \\
\hline Arora \& Romijn & The empty rhetoric of poverty reduction at the base of the pyramid & 2012 & Organization & $\mathrm{BoP}$ & 12 \\
\hline Igoe & Scaling up civil society: Donor money, NGOs and the pastoralist land rights movement in Tanzania & 2003 & Development and Change & NPE & 57 \\
\hline Uvin et al. & Think large and act small: Toward a new paradigm for NGO scaling up & 2000 & World Development & NPE & 37 \\
\hline Bailis et al. & Arresting the Killer in the Kitchen: The Promises and Pitfalls of Commercializing Improved Cookstoves & 2009 & World Development & NPE & 34 \\
\hline Westley \& Antadze & Making a difference: Strategies for scaling social innovation for greater impact & 2010 & Innovation Journal & NPE & 31 \\
\hline Bloom \& Chatterji & Scaling social entrepreneurial impact & 2009 & California Management Review & NPE & 26 \\
\hline Uvin \& Miller & Paths to scaling-up: Alternative strategies for local nongovernmental organizations & 1996 & Human Organization & NPE & 24 \\
\hline Uvin & Fighting hunger at the grassroots: Paths to scaling up & 1995 & World Development & NPE & 23 \\
\hline Kolavalli \& Kerr & Scaling up participatory watershed development in India & 2002 & Development and Change & NPE & 20 \\
\hline Austin et al. & Social and commercial entrepreneurship: Same, different, or both? & 2006 & Entrepreneurship: Theory and Practice & SE & 367 \\
\hline Mair \& Marti & Entrepreneurship in and around institutional voids: A case study from Bangladesh & 2009 & Journal of Business Venturing & SE & 109 \\
\hline Mair \& Martí & Social entrepreneurship research: A source of explanation, prediction, and delight & 2006 & Journal of World Business & SE & 350 \\
\hline McMullen & $\begin{array}{l}\text { Delineating the Domain of Development Entrepreneurship: A Market-Based Approach to Facilitating } \\
\text { Inclusive Economic Growth }\end{array}$ & 2011 & Entrepreneurship: Theory and Practice & SE & 23 \\
\hline Seelos \& Mair & Social entrepreneurship: Creating new business models to serve the poor & 2005 & Business Horizons & SE & 143 \\
\hline Seelos \& Mair & Profitable business models and market creation in the context of deep poverty: A strategic view & 2007 & Academy of Management Perspectives & SE & 118 \\
\hline Yunus et al. & Building social business models: Lessons from the grameen experience & 2010 & Long Range Planning & SE & 102 \\
\hline
\end{tabular}




\begin{tabular}{|c|c|c|c|c|c|}
\hline Viswanathan et al. & Exchanges in marketing systems: The case of subsistence consumer-merchants in Chennai, India & 2010 & Journal of Marketing & SMP & 45 \\
\hline Viswanathan et al. & Understanding consumption and entrepreneurship in subsistence marketplaces & 2010 & Journal of Business Research & SMP & 34 \\
\hline Viswanathan et al. & $\begin{array}{l}\text { Ingraining product-relevant social good into business processes in subsistence marketplaces: The } \\
\text { sustainable market orientation }\end{array}$ & 2009 & Journal of Macromarketing & SMP & 31 \\
\hline Viswanathan et al. & $\begin{array}{l}\text { Designing marketplace literacy education in resource-constrained contexts: Implications for public policy } \\
\text { and marketing }\end{array}$ & 2009 & Journal of Public Policy and Marketing & SMP & 25 \\
\hline Weidner et al. & Marketing to subsistence consumers: Lessons from practice & 2010 & Journal of Business Research & SMP & 22 \\
\hline $\begin{array}{l}\text { Sridharan \& } \\
\text { Viswanathan }\end{array}$ & Marketing in subsistence marketplaces: Consumption and entrepreneurship in a South Indian context & 2008 & Journal of Consumer Marketing & SMP & 21 \\
\hline Viswanathan \& Rosa & $\begin{array}{l}\text { Understanding subsistence marketplaces: Toward sustainable consumption and commerce for a better } \\
\text { world }\end{array}$ & 2010 & Journal of Business Research & SMP & 19 \\
\hline Viswanathan et al. & $\begin{array}{l}\text { Understanding and enabling marketplace literacy in subsistence contexts: The development of a consumer } \\
\text { and entrepreneurial literacy educational program in South India }\end{array}$ & 2008 & $\begin{array}{l}\text { International Journal of Educational } \\
\text { Development }\end{array}$ & SMP & 18 \\
\hline Rivera-Santos et al. & Bridging the institutional divide: Partnerships in subsistence markets & 2012 & Journal of Business Research & SMP & 17 \\
\hline Viswanathan et al. & Marketing interactions in subsistence marketplaces: A bottom-up approach to designing public policy & 2012 & Journal of Public Policy and Marketing & SMP & 16 \\
\hline Elaydi \& Harrison & Strategic motivations and choice in subsistence markets & 2010 & Journal of Business Research & SMP & 13 \\
\hline Chikweche \& Fletcher & Understanding factors that influence purchases in subsistence markets & 2010 & Journal of Business Research & SMP & 11 \\
\hline
\end{tabular}

' Keywords search: BoP: Bottom OR Base AND Pyramid OR BOP; MFI: Microfinance* OR Microcredit* OR Micro-finance OR Micro-credit* OR Microenterprise OR Microenterprise* OR MFI; SE: Social Enterprise* OR Business OR Social Entrepreneur* OR Social Entrepreneurhsip AND Povety OR Need* OR Growth OR Development OR Developing Count;; CSR: Corporate Social Responsibility OR CSR AND Poverty OR Development OR Developing Count*; SMP: Subsistence Market* OR Marketplaces; NPE: NPO OR NPE OR Nonprofit OR Not-for-profit OR NGO OR Impact AND Expansion OR Growth OR Scaling-up OR Expansion; IB: Inclus* AND Business* OR Market OR Growth 